\title{
Covid-19: equal response and unequal interests
}

\author{
Hartmut Kliemt ${ }^{1}$ (D)
}

Received: 21 July 2020 / Accepted: 25 August 2020 / Published online: 19 November 2020

(c) Springer-Verlag GmbH Germany, part of Springer Nature 2020

\begin{abstract}
The greatest risks of Covid-19 are not arising from its direct effects on morbidity and mortality but from exaggerated aspirations to control such effects politically. A swift transformation from an epidemic to an endemic state of affairs may in case of a disease with comparatively low and unequally distributed mortality like covid-19 be an option, too. This needs to be laid out but it is not the task of science to plead for this or any other option.
\end{abstract}

Keywords Life-years lost $\cdot$ Lives lost $\cdot$ Non-medical nature of tradeoffs

When Covid-19 hit, citizens of constitutional democracies around the world accepted physical distancing as expressive of fundamental respect for the life and personal integrity of each and every citizen. Constrained by and supportive of constitutionalized "priority of liberty" the tribute paid to the individual in public opinion should be registered with satisfaction by all adherents of rule of law societies. Yet, since "the power of the mighty hath no foundation but in the opinion and belief of the people" [(Hobbes 1990), 16] the presently dominant opinion that politics should do "whatever it takes" to rescue lives needs to be counter-balanced by an open discussion of the fundamental trade-offs between competing interests that alternative policies involve.

After physical distancing makes the economic costs of preventing deaths increasingly visible it starts to dawn on citizens that despite the tremendous costs that have already been incurred, the virus persists and the pandemic will be looming large until basic herd immunity arises either naturally through infections or artificially through a vaccine. In states in which they are constitutionally entitled to do so, citizens will increasingly question the suitability of government measures of coercive physical distancing — and rightly so.

My thanks are to Friedrich Breyer for imposing again his discipline of continuous criticism on me.

Hartmut Kliemt

hartmut.kliemt@t-online.de

1 Behavioral and Institutional Economics, Justus Liebig University, Giessen, Germany 


\section{Unequally at risk, equally coerced}

Practically all people are affected by coercive state measures of imposing physical distancing. Practically all who have not yet been infected with Covid-19 can contract the disease. In that sense each and everybody is equally affected by the virus. However, in particular the risks of dying from an infection are not equal. Young as well as healthy individuals can overwhelmingly expect to survive an infection typically with rather minor symptoms and mostly with a prospect of full recovery.

Societies that have managed to "flatten the curve" could instead have let the virus run its course and could still do so in the expectation that the numbers of infected individuals would peak on relatively short notice. Foreseeably, around peak time hospital capacities would have been and still might be insufficient to provide state of the art care for all patients. This would have led and still might lead to dramatically visible forms of triage. Yet, since concealed forms of triage are already practiced by letting elderly die out of the public eye in nursing homes it cannot be true that all forms of triage are literally unacceptable in a constitutional democracy.

Proclamations to the contrary will not prevent scarcity and trade-offs from making themselves felt in the lives of citizens with diverse private interests. Such public lies will raise expectations that, proving unsustainable, will eventually delegitimize constitutional democracy (Kuran 1995).

For those who are not old and/or chronically ill in rich societies a swift Covid19 epidemic with a rather mild disruption of the economy will seem increasingly more attractive when the economic disruption by strict physical distancing is extended. Among the poor in poor societies who have no access to ventilators and ICUs anyway, physical distancing will increase mortality risks arising from malnutrition etc. beyond those incurred when a Covid-19 epidemic would run its course. In any event, unless infection numbers can be kept low until basic herd immunity emerges "flattening the curve" will have and will be perceived as having merely a relatively minor impact on overall mortality.

Since severe cases of Covid-19 are disproportionally concentrated in groups with reduced life-expectancy, the loss of expected life-years due to overcrowding of ICUs will be much smaller than if the number of deaths were weighted with average life-expectancy. The distinction between life-years and lives lost by Covid-19 applies independently of the development status of countries since in less developed countries the proportion of older and chronically ill people is smaller due to the general "paradox" of health care improvement: the better the health care in a society the worse the state of health (e.g. the better dialysis is the more chronically ill End-State-Renal-Disease patients).

Since we are not "all in this together" in the sense of being equally affected, the real puzzle is why the acceptance of norms of equal protection of citizens' rights became politically so forceful that the initial physical distancing measures were accepted around the world. A speculative explanatory sketch based on aspiration adaptation may run as follows: Since WWII the world became a much 
better place (Pinker 2012). People have adapted their aspiration levels concerning the care and security they expect to be guaranteed by governments not only for themselves and those who are close to them but also for remote individuals. In consequence public appeals to politically do whatever it takes are invited to capture the moral high ground and to monopolize public discourse.

Nevertheless, the degree to which such aspirations are extended from concrete and close-family, friends, close colleagues - to statistical, impersonal lives in the present crisis remains astonishing. We do not really know why that is so (that modern electronic social networks made the world "smaller" can at best be part of the explanation).

Though discussing the presence of Covid-19 as a normal fact of life is still uncommon, this "new normal" must eventually be acknowledged as such in public discourse. After political systems have reaffirmed their willingness to protect individual lives at tremendous costs to the community, risks that individual lives will be underappreciated in future symbolic and real politics should not worry us much. Worrisome for those who wish humankind well is rather that foreseeably the global nature of the pandemic will be held against globalization, speedy transportation, the international division of labor and all the other "causes of the wealth of nations".

\section{Globalization and Covid-19}

Despite its bad press and its downsides globalization has overall been for the good of humankind. Even pandemics do not unequivocally count against it: "Failure to understand the profound difference between the outbreak of a familiar disease amid an experienced population and the ravages of the same infection when loosed upon a community lacking acquired immunities is, indeed, at the bottom of the failure of previous historians to give adequate attention to the whole subject." [(McNeill 1989), 22].

Since avoiding the failure of former historians is highly relevant for developing "adequate attention to the whole subject" in the present crises rehearsing some historical facts seems appropriate: After the first wave of overseas trade and the violent conquests accompanying it had run their course, international blue water trade and travel continually spread a trickle of disease which kept populations at least partially "experienced". Unlike the Amerindians in the 16th or the Europeans in the sixth and fourteenth century who went under in droves when smallpox and plague hit unexperienced formerly isolated populations, the impact of diseases became-as bad as it was-more limited after the eighteenth century: Ever increasing globalization had increasingly transformed potentially epidemic into endemic diseases (a process complemented, respectively completed by increasing vaccination rates).

Against Covid-19, former exposure via globalization could not provide basic protection because all humankind was unexperienced of the new virus. The spread was clearly supported by globalization when the world was not taking the virus seriously. This was quite understandable after the Sars-1 crisis had dwindled down without causing major damage. Clearly, the world could have been and could get better prepared to respond adequately in such cases-an obvious 
measure being that of putting bulkheads into place that could be closed whenever necessary to prevent fast communication of a disease.

Yet, as MacNeill's observation suggests, absent vaccines, a controlled globalization of a disease and its transformation into a globally endemic condition sees to it that mankind will continuously be exposed to the disease. There will be no subpopulations that are completely "unexperienced" and thereby prone to experience violent epidemics. Absent vaccination, globally endemic status of a disease may in general be the best insurance against violent pandemics.

We must not ignore that the general expansion of markets, trade and the division of labor has since the eighteenth century prevented the worst epidemic devastations by disease. With its accompanying economies of scale what has been called "a splendid exchange" (Bernstein 2009) brought this about along with the wealth it created. It led humankind out of the Malthusian trap and to a global average life expectancy of some 70 years, lower absolute poverty rates, lower infant mortality etc. To deny this is not only foolish but in itself an ethically wrong act.

\section{Final remarks}

The greatest risks of Covid-19 are not arising from its direct effects on morbidity and mortality but from exaggerated aspirations to control such effects politically. We need to redirect our aspirations from avoiding yet unknown risks altogether-which is impossible-towards improving resilience should novel risks materialize.

As far as the latter is concerned, the homogeneity of present responses prevents inter-jurisdictional learning. For a limited time, it might be advisable to restrict international travel to the extent necessary not only to buy time but also for learning from response-heterogeneity how to better cope with this and future potential pandemics. This being said we should not give in to our own hindsight biases and acknowledge that in view of the radical uncertainty they were facing governments around the world responded remarkably well. Now is the time of searching sustainable compromises by means of "government by discussion". As part of that discussion evidence should be presented by scientists not as "recommendation" but without any intent to influence politics according to the political values scientists happen to endorse.

\section{Compliance with ethical standards}

Conflict of interest The author declare that he has no conflict of interest. 


\section{References}

Bernstein WL (2009) A splendid exchange: how trade shaped the world. Atlantic Books, London Hobbes T (1990) Behemoth or the long parliament. University of Chicago Press, Chicago

Kuran T (1995) Private truths, public lies: the social consequences of preference falsification. Harvard University Press, Cambridge

McNeill W (1989) Plagues and peoples. Anchor, Norway

Pinker S (2012) The better angels of our nature: why violence has declined. Penguin Books, London Reprint

Publisher's Note Springer Nature remains neutral with regard to jurisdictional claims in published maps and institutional affiliations. 